\title{
Criminal Responsibility of Village Chief in Approving Indigenous Inheritance Necessity Certificate
}

\author{
Febriyan Yoga Sanjaya*; Burhanudin Harahap \\ Faculty of Law, Universitas Sebelas Maret, Indonesia \\ Email: Febriyan_y@yahoo.com
}

http://dx.doi.org/10.18415/ijmmu.v5i4.397

\begin{abstract}
This paper aims to identify and analyze the legal responsibilities of village heads in passing a certificate of inheritance. This research is normative research. The results of the study found that the village head in the case of ratifying the inheritance certificate inadvertently could violate article 56 of the Criminal Code concerning persons who participate in criminal acts, assist in criminal conduct and may also violate the articles of False Oath and False Statement Article 242 paragraph (1) of the Criminal Code.
\end{abstract}

Keywords: Responsibility; Village Chief; Literacy Sheet

\section{Introduction}

The division system for making inheritance certificates (SKW) in Indonesia is still classified into three groups. There are three officers who are authorized to make a certificate of heir, namely Notary for Chinese, Heritage Hall (BHP) for foreign non-Chinese group or made by heirs on paper witnessed by the Village Head/ Village Head and reinforced by the Head of Sub- the Indonesian Citizens (WNI) Bumiputera $^{1}$. The subsequent consequence of law with the death event is the issue of how to manage and sustain the rights and duties of a deceased person. The making of Inheritance Certificate is hereinafter abbreviated as SKW. It is the implementation of the SKW inheritance provision. Not an easy job. What happens on the ground is that a certificate of inheritance can be made sufficiently by one of the heirs alone. The heirs are facing the Village Head/ Village Head to sign the SKW without knowing the truth of the content of the SKW. The village head should know the family history of submitting the SKW by checking the population records in the kelurahan and knowing who the heirs have just signed the SKW. This facilitates the manipulation of the heirs. Manipulation of the heirs that can be done is transferring the rights to the land of inheritance to another party without the consent of the other heirs. The transfer of land rights occurs because the name is not listed in the certificate of inheritance (SKW). The impact of transfer of right to inheritance is causing damage to the heirs whose names are not listed in the certificate of inheritance. The village head who should benefit the citizens precisely cause disputes and cause economic losses for the heirs not listed in SKW.

\footnotetext{
${ }^{1}$ Herlien Budiono. (2013). Kumpulan Tulisan Hukum Perdata di Bidang Kenotariatan, Citra Aditya Bakti, Bandung, p. 84.
} 
The making of SKW which is based on the last residence has an obstacle if the last address of the testator is not the same as the heirs which is the reason for filing SKW is only done by the closest heir to facilitate the inheritance process the ease of submitting SKW with only one heir causes the ease of making SKW without including all the heirs. It is also facilitated by the village head endorsing/ signing SKW without looking directly at the signing process of SKW and without checking the correctness of the supporting data. The village head should see the SKW signing process directly by his heirs who legally provide certainty and avoid the falsification or data errors, but this is not done by the village head and the village head directly validate/ know and sign the SKW so that in legal deed validate the letter the indigenous inheritance of the village head raises the dispute even causing harm to the heir whose name is not included in the certificate of inheritance. Therefore, it is important to discuss "the Criminal Responsibility of the Village Head in Approving the Inheritance Certificate".

\section{Methodology}

Research is essentially "a search" rather than merely observing carefully an object that is easily held in the hand. Research is a translation of the English language that is research. Thus meaning "seek back"2. The type of research used in this study is law juridical normative research or can be called also doctrinal legal research. Soejono Soekanto mentioned that normative research is a legal research that only examines library materials so that it is also called legal research literature.

Normative or doctrinal legal research looking from literature studies of books or written laws, analyzing from writing and not looking at existing social facts, explaining existing data with words or statements rather than with numbers, so legal juridical legal research has a very wide scope. The nature of the study is descriptive analytical in accordance with the problems and objectives in this study to provide as much data as possible about supporting data, circumstances or other symptoms, the intention is primarily to reinforce the hypotheses, in order to assist in reinforcing the new theories. If the knowledge of a problem is sufficiently done eksplantoris research that is primarily intended to test certain hypotheses ${ }^{3}$.

\section{Discussion Criminal Responsibility of Village Chief in Approving Indigenous Inheritance Necessity Certificate}

The making of the certificate of heir is done by different officials based on the population. There are three officers who are authorized to make a certificate of heir, namely Notary for Chinese, Heritage Hall (BHP) for foreign non-Chinese group or made by heirs on paper witnessed by the Village Head/ Village Head and reinforced by the Head of Sub- Indonesian citizen Bumiputera ${ }^{4}$. Article 111 Paragraph (1) Sub-Paragraph c of the Minister of Agrarian Regulation/ Head of National Land Agency No.3 Year 1997 concerning Provisions on the Implementation of Government Regulation no. 24 of 1997 concerning Land Registration which contains provisions on the guidance of making the Certificate of the Heirs in the implementation of the transfer of land rights which states that the Letter of Evidence as an heir can be in the form of:

1. Testament of the heir or

2. Court ruling or

3. The appointment of a judge/ court chairman or

4. For indigenous Indonesian citizens (indigenous), certificate

\footnotetext{
${ }^{2}$ Bambang Sunggono. (1998). Metodelogi Penelitian Hukum, Ctk. Kedua, PT. Rajagrafindo Persada, Jakarta. p. 27-28.

${ }^{3}$ Soejono Soekanto. (2012). Pengantar Penelitian Hukum, Universitas Indonesia (UI-Press), Jakarta, p. 10.

${ }^{4}$ Herlien Budiono. (2013). Kumpulan Tulisan Hukum Perdata di Bidang Kenotariatan, Bandung: Citra Aditya Bakti, p. 84.
} 
heirs made by the heirs witnessed by 2 (two) witnesses and strengthened by the head of the village/ subdistrict and the sub-district where heirs live at the time of death ${ }^{5}$.

SKW or certificate of inheritance is an underwritten deed made by an inheritor whose contents determine who the heirs are upon the heir to pass away and how much the right of his share of inheritance. SKW is generally made at the request of one or several of the heirs. Although SKW is recognized in both law and jurisprudence, there is no general provision governing the form and content of SKW. The meaning of Certificate of Inheritance (Verklaring van Erfpacht) according to R. Soegondo Notodisoerjo is a Certificate made by Notary for the Chinese and foreign Eastern and the village head for the indigenous group which contains the provisions of who according to the law is a legitimate heir of a person who die.

Legal responsibility, which in English is called the theory of legal liability, its Dutch language, is called de theorie van wettelijke aansprakelijkheid, whereas in its german called die hheorie der haftung is a theory that analyzes the responsibilities of legal subjects or perpetrators who have done an act against the law or a criminal offense resulting in loss or disability, or death of another person.

In Indonesian, the word responsibility means the state is obliged to bear everything (if what happened what can be prosecuted, blamed, diperkarakan, and so on). Bearing is defined as being willing to assume costs (taking care of, maintaining), guaranteeing, declaring state of availability to perform obligations.

The definition of responsibility in detail, presented following algra et al., Defines responsibility or verantwoordelijkid is:

"Obligation to bear responsibility and bear the harm suffered (if prosecuted), both in law and in the field of administration"6.

There are two types of liability in this definition:

1. Criminal liability

2. Civil liability

Legal liability is the type of liability imposed on a legal subject or perpetrator who commits an offense or a crime. The concerned may be required to pay compensation and / or run the criminal. While the administrative responsibility is the responsibility charged to a person who made an administrative error, such as, for example a doctor who has committed an administrative offense, then the relevant license can be revoked practice.

According to Hans Kelsen in his theory of the legal responsibility of declaring that a person is legally responsible for a particular deed or that he assumes legal liability, the subject means that he is responsible for a sanction in terms of contradictory acts ${ }^{7}$.

Ridwan Halim defines the legal responsibility as a further consequence of role execution, whether it is a right and a duty or a power. In general, legal responsibility is defined as the obligation to do something or behave in a certain way does not deviate from existing rules.

\footnotetext{
${ }^{5}$ Zainuddin Ali. (2011). Pelaksanaan Surat Keterangan Hak Waris bagi Golongan Penduduk di Indonesia, Sinar Grafika, Jakarta. p. 39.

${ }^{6}$ N. E. Algra., dkk. (1983). Kamus istilah hukum fockema andreae belanda indonesia, Jakarta: binacipta. p. 68.

${ }^{7}$ Hans Kalsen. (2006). Teori Umum tentang Hukum dan Negara, Bandung: PT. Raja Grafindo Persada. p. 95.
} 
Purbacaraka believes that legal responsibility is sourced or born on the use of facilities in the application of the ability of each person to exercise his rights and perform his obligations. It further stipulates that any execution of obligations and any use of rights whether done inadequately or adequately carried out is essentially still to be accompanied by accountability, as well as the exercise of power.

Understanding the above can be concluded that the legal responsibility is a result that must be the responsibility of the legal subjects of a legal act done in a certain role which if the legal action will be subject to sanctions in the form of sanctions compensation or legal sanctions.

In the Circular Letter of the Ministry of Home Affairs the Directorate General of Agrarian Affairs dated December 20, 1969 Number Dpt/12/63/12/69 on Certificate of Inheritance and Proof of Citizenship there is a phrase which soundsThere are three officials authorized to make a certificate of heir, namely Notary for Chinese, Heritage Hall (BHP) for non-Chinese foreigners or made by heirs on paper witnessed by the Village Head and strengthened by the Camat for the Indonesian Citizens Bumiputera.

Seeing the contents in the Circular Letter of the Ministry of Home Affairs of the Directorate General of Agrarian Affairs dated December 20, 1969 the number Dpt/12/63/12/69 on Certificate of Inheritance and Citizenship Proof which is so, it can be concluded that the appointment of village heads known by the subdistrict head as administrative officer the state having the authority to witness the inheritance certificate made by the heirs, even though the village head does not have the authority set forth in the legislation for that matter, because at that time it is necessary to solve the problems that arise regarding the certificate of inheritance. But freies ermessen is a form of action that goes against the principle of legality and there should be further action for the formation of rules legislation that can generate authority either by attribution, delegation or mandate.

If the Village Head is justified/ witnessed/ known is their (legal Subject) whose names and signatures are listed in the Inheritance Certificate, which means to verify/ see that they are the villagers concerned and are legitimate heirs, meaning they reside in one village/ kelurahan and the same subdistrict. For such a case the Village Head shall be responsible for their existence as well as their positions as heirs. Therefore, if the Village Head still participates to justify/ know/ witness and sign the Certificate of Inheritance for those whose names are listed in the Inheritance Letter, then the actions of the Village Head and Head of Camat can be categorized as a criminal act providing false information and misuse of authority because roles and legal actions that are done not under the laws of jabatanya and Carry out carelessness in legalizing SKW and harming the heirs whose names are not listed in the SKW.

From the research conducted interview to complete the secondary data to describe the case, especially to reinforce the theory of law, in order to assist in strengthening the theories with the relevant parties namely the former village chief Nguter Mr. Tinta Joko Margono he gave information that "there are indeed the heirs who provide data such as family cards, identity cards, incomplete death certificates, all heirs of the heirs filing a certificate of inheritance included in SKW are only heirs who live in the village/ village only while those outside the area are not included. I only validate the SKW sometimes I also see/ witnessed the SKW is signed but also I do not know the signing of the SKW has been signed by the new heirs in submitted to me for the sahkan, while the reason I validate the SKW because of the belief that from the explanation of such heirs who are not included because of distance and if included in SKW also will not be able to sign in the SKW and therefore part of the heirs will be given in the form of proceeds from the sale of this estate, from my heirs' legitimate because SKW is basically under the hands and the responsible are the heirs who make the SKW ". In the above case the village head is negligent and the lack of caution in which the village head passively lets the criminal act of falsifying the inheritance certificate. 
The village head in terms of validating the indigenous heirs' validity certificate has the role of justifying the contents of the inheritance certificate made by the heirs along with the witnesses, in the case of the village head justifying or endorsing an incorrect certificate of inheritance resulting in a dispute that benefits some heirs and harms some other heirs whose names are not listed in the SKW, so that in the event of a dispute the head of the village may be subject to Article False Oath and False Statement, Article 242 paragraph (1) of the Criminal Code (KUHP), whichever one the law determines to give statements on oath or to bring a legal effect to such information, deliberately giving false statements on oath, whether oral or written, personally or by its special attorney, is punishable by the maximum imprisonment seven years.

An explanation is false, if part of the description is false unless this is such that it can be estimated that it was inadvertently given in giving false information. counterfeiting deeds due to his misalignment in examining SKW is not done which causes harm to the heirs.

The village head as though not directly the main actor in the fraud of the deed, but by law the village head violated Article 55 participates in Article 55 of the Criminal Code. Convicted of a criminal offense:

A person who commits, commits, or contributes to the act: Any person who by giving, by contract, by any use of power or influence, violence, threat or trickery or by giving an opportunity, effort or explanation, deliberately persuades to do any act.

Of those persons in the sub-subdivisions that may be accountable to him are only those deliberately persuaded by them, and with the consequences. Article 56 of the Criminal Code. Convicted as a person who helps to commit a crime:

Whoever deliberately helped do the crime;

Whoever deliberately provides an opportunity, effort, or information to commit the crime.

By "medepleger" in Article 55 of the Criminal Code. According to R. Soesilo, "participate in" in the sense of the word "together do". At least there should be two people, is the person who did (pleger) and the person who helped (medepleger) criminal events. Here it is requested that the two persons all carry out the act of execution, so do the elements or elements of the criminal act. It is not permissible for example to do only the act of preparation or acts of a helpful nature, for if so, then the person who helps it does not enter "medepleger" but is punished as "help to do" (medeplichtige) in Article 56 of the Criminal Code $^{8}$.

While on Article 56 of the Criminal Code, R. Soesilo explains that people "help do" if he deliberately provide such assistance, on or before (so no after) the crime was committed. If the assistance is provided after the crime has been committed, the person commits an act of "conspiracy" or "tadah" violates Article 480 of the Criminal Code, or the criminal incidents mentioned in Article 221 of the Criminal Code'.

Hazewinkel-Suringa's opinion, Hoge Raad of the Netherlands which sets out two conditions for the existence of the criminal act, namely: First, the conscious cooperation between the actors involved, which is a shared desire between them; Second, they must jointly carry out the will. The difference between "doing" and "helping to do". According to him, based on the theory of subjectivity, there are 2

\footnotetext{
${ }^{8}$ R. Soesilo. (1991). Kitab Undang-Undang Hukum Pidana Serta Komentar-Komentarnya Lengkap Pasal Demi Pasal. Politeia: Bogor, p. 167.

${ }^{9}$ R. Soesilo. (1991). Kitab Undang-Undang Hukum Pidana Serta Komentar-Komentarnya Lengkap Pasal Demi Pasal. Politeia: Bogor, p. 169.
} 
(two) measures used: The first measure is about intentional intent which is in the perpetrator, while the second measure is about the interests and purposes of the perpetrator ${ }^{10}$.

The size of intent may be;

1. On the will of the perpetrator to actually commit a crime, or just to provide assistance, or

2. The will of the perpetrator to actually achieve the result of which is an element of a criminal offense, or to merely act or help if the principal actor wants it.

Whereas, the measure of the same interests or objectives is that if the perpetrator has his own interests or own goals, or only helps to fulfill the interests or to achieve the goals of the principal actor.

Based on the above explanation we may conclude the fundamental difference of "taking part" of crime by "helping to do" criminal act. In "taking part" there is a conscious cooperation between the perpetrators and they jointly carry out the will, the perpetrators have a purpose in committing the crime. Whereas in "help do", the will of the person who helps do is to help the main actor achieve his goal, without having his own goal. So that the village head in the case can be subjected to passive criminal falsification. Helping to do "(medeplichtige) in Article 56 of the Criminal Code and also" medepleger "in Article 55 of the Criminal Code in the case above the village head in passing the certificate of inheritance containing only partial heirs and the removal of other heirs is a criminal act of letter fraud which is done by the heirs whose interest is facilitated by legalization by the competent authority in this case the village head which the village head can violate article 56 of the Criminal Code.

\section{Conclusion}

Inheritance certificate made under the heirs by the heirs and approved by the village head in this case acting as village officials in validating the SKW should not immediately give validation and signature but do checking the data is not done by the head of the village remember the head the village considers that the deed under hand in this case SKW is the full responsibility of the heirs it is not true because every official who signed the signature in a letter must have the roles and responsibilities of each of which the village head may be subject to legal sanctions in criminal entangled Article 56 of the Criminal Code on the person assisting the conduct. It may also be subject to the provisions of the False Oath and Counterfeit Information, Article 242 paragraph (1) of the Criminal Code (KUHP), whichever the state of the law determines to give statements on oath or to bring a legal effect to such information, by deliberately giving false statements on oath, whether oral or written, personally or by his special attorney, is punishable by a maximum imprisonment of seven years.

\section{References}

Algra, N. E. (1983). Kamus Istilah Hukum Fockema Andreae Belanda Indonesia. Jakarta: Binacipta.

Ali, Z. (2011). Pelaksanaan Surat Keterangan Hak Waris Bagi Golongan Penduduk Di Indonesia. Jakarta: Sinar Grafika.

Budiono, H. (2013). Kumpulan Tulisan Hukum Perdata Di Bidang Kenotariatan. Bandung: Citra Aditya Bakti.

Hans Kalsen. (2006). Teori Umum Tentang Hukum Dan Negara, Bandung: PT. Raja Grafindo Persada.

\footnotetext{
${ }^{10}$ R. Soesilo. (1991). Kitab Undang-Undang Hukum Pidana Serta Komentar-Komentarnya Lengkap Pasal Demi Pasal. Politeia: Bogor, p. 201.
} 
Herlien Budiono. (2013). Kumpulan Tulisan Hukum Perdata Di Bidang Kenotariatan, Bandung: Citra Aditya Bakti.

Salim HS Dan Nurbani. E. S. (2015). Penerapan Teori Hukum Pada Penelitian Desrtasi Dan Tesis. Jakarta:PT Rajagrafindo Persada.

Soekanto. S. (2012). Pengantar Penelitian Hukum. Jakarta:Universitas Indonesia(UI-Press), Jakarta.

Sunggono, B. (1998). Metodelogi Penelitian Hukum, Jakarta :PT. Rajagrafindo Persada.

\section{Copyrights}

Copyright for this article is retained by the author(s), with first publication rights granted to the journal.

This is an open-access article distributed under the terms and conditions of the Creative Commons Attribution license (http://creativecommons.org/licenses/by/4.0/). 